International Journal of Pharmaceutics \& Pharmacology

EDW SER

Available Online: http://ijpp.edwiserinternational.com

\title{
Boswellic Acids Pretreatment Enhances the Bioavailability and Hypoglycemic Action of Metformin in Rats: Involvement of CYP3A Inhibition
}

\author{
Sujatha Samala and Ciddi Veeresham*
}

Department of Pharmacognosy, University College of Pharmaceutical Sciences, Kakatiya University, Telangana, India

Article info

Received 26 November 2018

Revised 28 December 2018

Published 31 December 2018

*Corresponding author: Ciddi Veeresham, Department of Pharmacognosy, University College of Pharmaceutical Sciences, Kakatiya University, Telangana, India, E-mail: ciddiveeresham@yahoo.co.in

\begin{abstract}
Herbal antidiabetic preparations are often used as an add-on therapy in diabetes. Hence in the present investigation the effect of boswellic acids (BA) on the bioavailability and hypoglycemic action of metformin in normal as well as diabetic rats was studied. In normal and streptozotocin induced diabetic rats the combination of metformin with $B A$ increased all the pharmacokinetic parameters such as $C_{\max }, A U C 0-n, A U C_{\text {total }}, t_{1 / 2}, M R T$ and decreased the clearance, Vd markedly as compared to control group. In intestinal and liver microsomes BA at 10 $\mu \mathrm{M}$ has shown CYP3A4 inhibitory activity significantly $(p<0.01)$, compared with the vehicle group. In pharmacodynamic studies, the combination of metformin with BA provided significant protection against the diabetes induced alterations in the biochemical parameters. In addition, the combination of metformin with BA also improved the total antioxidant status and decreased lipid peroxide levels significantly in diabetic rats compared with BA and metformin alone treated groups. The results revealed that BA led to the PK/PD changes have been due to metformin increased bioavailability, decreased volume of distribution and clearance by inhibiting the CYP3A enzyme. In conclusion, add-on preparations containing boswellia may increase the bioavailability and hypoglycemic action of metformin, and hence should be cautiously used.
\end{abstract}

Keywords: Boswellic acids; Metformin; Pharmacokinetics; CYP3A; Pharmacodynamics

\section{Introduction}

Herbal drugs have received great attention as alternative medicines in recent years and are also referred to as a dietary supplement or health food. The use of complementary therapies for treatment of diabetes is ever increasing, and often remains unnoticed by a physician [1]. Diabetic patients often consume herbal preparations along with routinely prescribed antidiabetic agents [2]. Metformin is a biguanide of oral hypoglycemic agent which is widely used for the treatment of type 2 diabetes mellitus and which has poor bioavailability (around 40\%). There are several PK and PD interaction studies of metformin with Allium sativum [3] and Gymnema sylvestre extracts [4], thus there is a need to study the interaction between metformin and other drugs to avoid adverse effects. Boswellia serrata, known as sallaki or salai guggal or frankincense, is widely used to treat various types of blood disorders, inflammatory health ailments, pain and cardiac debility [5]. The major active component in sallaki are mixture of Boswellic acids (BA), includes $\alpha$ Boswellic acid, $\beta$-Boswellic acid, 3-Acetyl- $\alpha$-Boswellic acid, 3-Acetyl- $\beta$-Boswellic acid, 11-keto- $\beta$-Boswellic acid and 3-Acetyl-11-keto- $\beta$-Boswellic acid. Many studies have shown that Boswellia serrata and its major 
Citation: Samala $S$ and Veeresham C. Boswellic acids Pretreatment Enhances the Bioavailability and Hypoglycemic action of Metformin in Rats: Involvement of CYP3A Inhibition. Int J Pharm Pharmacol 2018; 2: 132. doi: $\underline{10.31531 / 2581-3080.1000132}$

component, BA have various pharmacological activities, such as anti-inflammatory [6], anti-arthritic [7] and antidiabetic [8]. There are several in-vitro reports of boswellia on inhibition of microsomal enzyme system (CYP1A2, 2C8, 2C9, 2D6 and 3A4) and may lead to change in the bioavailability of concomitant drug $[9,10]$. In view of the effect of boswellia on CYP enzymes especially on CYP3A and also antidiabetic properties, its presence in herbal preparations may influence the bioavailability and hypoglycemic action of metformin, particularly because the latter is metabolized by CYP3A. Therefore, the aim of the present investigation was to study the effect of boswellia on pharmacokinetics and pharmacodynamics of metformin in normal and streptozotocin induced diabetic rats.

\section{Experimental}

Drugs and chemicals: Metformin and gliclazide were obtained as gift samples from Dr. Reddy's laboratories (Hyderabad, India). Acetonitrile (HPLC-grade), ammonium acetate and glacial acetic acid of AR grade (99.5\%) were procured from Merck Specialties Pvt. Ltd., Mumbai. Boswellic acid (BA) supplied by Yucca Enterprises, (Mumbai, India). Ascorbic acid, $\alpha, \alpha-$ diphenyl- $\beta$-picrylhydrazyl (DPPH), 1,1,3,3-tetraethoxy propane (TEP), thiobarbituric acid and streptozotocin (STZ) were supplied by HiMedia Laboratories Pvt. Ltd, (Mumbai, India).

Animals and diet: Wistar Albino rats of male weighing $180-250 \mathrm{~g}$ were used in the study, after approval of experimental protocol by the Institutional Animal Ethical Committee (CPCSEA Reg. No.146/1999), Kakatiya University, Warangal. They were maintained under standard laboratory condition at ambient temperature. They were fed with pellet diet and water ad libitum.

\section{Pharmacokinetic Study}

PK Study in normal rats: Following an overnight fasted, rats were divided in to 2 groups $(n=6)$.

Group I: Metformin (100 mg/kg; p.o.) on $8_{\text {th }}$ day.

Group II: Pretreated with BA (100 mg/kg; p.o.) for 7 days, on the $8^{\text {th }}$ day metformin $(100 \mathrm{mg} / \mathrm{kg}$; p.o. $)$ followed by BA.

Blood samples were collected from the fasted rats $(16 \mathrm{~h}$ with water ad libitum) by retro-orbital vein puncture
[11] at time intervals of $0,0.5,1,2,4,6,8,12$ and $24 \mathrm{~h}$ into eppendroff tubes, serum was separated by centrifugation (8000 rpm for $15 \mathrm{~min}$ ) and stored at $20^{\circ} \mathrm{C}$ until further analysis.

Diabetes induction: To the overnight fasted rats diabetes was induced by IP injection of streptozotocin $(55 \mathrm{mg} / \mathrm{kg}$, b.w.), freshly dissolved in citrate buffer $(\mathrm{pH}$ 4.5) [12]. After $72 \mathrm{~h}$ retro orbital blood sampling was done and the serum glucose levels were measured. The fasting blood glucose level $>250 \mathrm{mg} / \mathrm{dl}$ and above were considered as diabetic and selected for the study.

PK Study in diabetic rats: Overnight fasted diabetic rats divided into 2 groups $(n=6)$ and the remaining procedure was done same as mentioned in PK study in normal rats.

HPLC analysis of metformin: Metformin was estimated by an earlier reported HPLC method [13]. HPLC system consisted of LC-10 ATVP solvent delivery module (Shimadzu, Kyoto, Japan), with Lichrosphere $100 \mathrm{RP} \mathrm{C}_{18}$ column was used. Rheodyne injection port with a $20 \mathrm{ul}$ sample loop and Hamilton syringe $20 \mu \mathrm{L}$ was used. The mobile phase consists of $0.15 \mathrm{M}$ ammonium acetate and acetonitrile $(90: 10 \mathrm{v} / \mathrm{v})$. The flow rate was $1.0 \mathrm{~mL} / \mathrm{min}$ and the effluent were monitored at $236 \mathrm{~nm}$. The total run time of the method was set at 10 minutes.

CYP3A activity by in-vitro method: CYP3A activity in microsomes (intestinal and liver) was estimated by using an earlier reported in-vitro method [14]. Principle involved in this method was, CYP3A4 converts erythromycin to $\mathrm{N}$-demethyl erythromycin and formaldehyde, detected by using Nash reagent which produces yellow color [15].

Erythromycin-N-demethylation assay: The mixture of microsomal suspension $(0.1 \mathrm{ml}, 25 \%)$, erythromycin $(0.1 \mathrm{ml}, 10 \mathrm{mM})$ and potassium phosphate $(0.6 \mathrm{ml}, 100$ $\mathrm{mM}, \mathrm{pH}$ 7.4) was incubated at $37^{\circ} \mathrm{C}$ along with $\mathrm{BA}$ at a concentration of $0.1,1$ and $10 \mu \mathrm{M}$. The reaction between these agents was initiated by adding NADPH $(0.1 \mathrm{ml}, 10 \mathrm{mM})$, and terminated after $10 \mathrm{~min}$, by adding ice cold trichloroacetic acid $(0.5 \mathrm{ml}, 12.5 \% \mathrm{w} / \mathrm{v})$ solution. It was centrifuged $(2000 \times \mathrm{g} ; 10 \mathrm{~min})$ to remove proteins. To $1 \mathrm{ml}$ of this supernatant $1 \mathrm{ml}$ of Nash Reagent (2 M ammonium acetate, $0.05 \mathrm{M}$ glacial acetic acid, $0.02 \mathrm{M}$ acetyl acetone) was added, and heated in a water bath at $50^{\circ} \mathrm{C}$ for $30 \mathrm{~min}$. After cooling, the absorbance was read at $412 \mathrm{~nm}$. The activity was calculated from standards (1-100 $\mu \mathrm{M}$ formaldehyde) 
Citation: Samala $S$ and Veeresham C. Boswellic acids Pretreatment Enhances the Bioavailability and Hypoglycemic action of Metformin in Rats: Involvement of CYP3A Inhibition. Int J Pharm Pharmacol 2018; 2: 132. doi: $\underline{10.31531 / 2581-3080.1000132}$

prepared by substituting sample with standard solution which were run in parallel. The CYP3A4 activity was expressed as $\mu \mathrm{M}$ of formaldehyde obtained per milligram of protein per hour [14].

\section{Pharmacodynamic Studies}

Antihyperglycemic study: Following an over-night fasted, diabetic rats were divided in to 4 groups $(n=6)$.

Group I: Diabetic control (Normal saline, p.o.)

Group II: Metformin (100 mg/kg; p.o.)

Group III: BA (100 mg/kg; p.o.)

Group IV: BA + metformin (100 mg/kg; p.o.)

Blood samples were collected from the fasted rats by retro-orbital vein puncture at time intervals of 0 (Initial fasting blood sample) and 2, 4, 6, 8, 12 and $24 \mathrm{~h}$ after the treatment into eppendroff tubes, serum was separated by centrifugation ( $8000 \mathrm{rpm}$ for $15 \mathrm{~min}$ ) and stored at $-20^{\circ} \mathrm{C}$ until further analysis. Blood glucose levels were analyzed by GOD-POD method [16].

Oral Glucose Tolerance Test (OGTT): Overnight fasted diabetic rats divided into 4 groups $(n=6)$ and treated same as mentioned in above study. For glucose tolerance test 30 minutes after the treatment all the group of rats were given D-glucose $(2.5 \mathrm{~g} / \mathrm{kg}, \mathrm{p} . \mathrm{o})$ and blood samples were collected at time intervals of 30, 60, 90 and 120 minutes for estimation of blood glucose levels, same as mentioned in earlier reported method [17].

Biochemical parameters estimation: For sub-acute study (28 days) grouping was done same as mentioned in antihyperglycemic study and were pretreated once a day for 28 days. During the study period, the body weight and blood glucose levels were recorded after 7 , 14, 21 and 28 days of the treatment. Whereas, Serum insulin, SGOT, SGPT, serum cholesterol, serum triglyceride and serum total protein levels were estimated after 28 days of the treatment same as mentioned in earlier reported method [18].

Determination of oxidative stress markers: The total antioxidant status and lipid peroxide levels of sub-acute study serum samples were determined by using DPPH [19] and thiobarbituric acid reaction methods [20]. The antioxidant status values were expressed in terms of $\mathrm{nM}$ of ascorbic acid and the lipid peroxide levels were expressed in terms of $\mathrm{nM}$ of malondialdehyde content in serum samples.

Statistical analysis: Data was expressed as mean \pm SD . The significance was determined by using one-way ANOVA (Dunnet's t-multiple comparison test). Results were considered to be statistically significant when $\mathrm{p} \leq$ 0.05 .

\section{Results and Discussion}

From the pharmacokinetic study of normal and diabetic rats it was found that the $\mathrm{C}_{\max }$ of metformin significantly increased in BA with metformin (1.51, 2.46 times), AUC0-n (2.07, 3.68 times), AUC total (2.36, 5.22 times), t1/2 (1.65, 2.32 times), MRT (1.46, 2.05 times), whereas the clearance and volume of distribution of metformin was decreased $0.43,0.73$ times in normal rats and $0.19,0.45$ times in diabetic rats, when compared with control group. Mean pharmacokinetic parameters of metformin in different groups of normal and diabetic rats is shown in Table 1 . The $\mathrm{T}_{\max }$ of metformin in both normal and diabetic groups was not altered by co administration with BA. The extent of erythromycin-N-demethylation (EMD) due to CYP3A activity was shown in Figures 1 and 2. In BA treated groups the level of EMD at $10 \mu \mathrm{M}$ concentration was significantly reduced $(\mathrm{P}<0.01)$ in the intestinal and liver microsomes when compared with vehicle control.

The significant increase in PK parameters $\left(\mathrm{C}_{\max }\right.$, $\mathrm{AUC}_{\text {oton, }}, \mathrm{AUC}_{\text {total }}, \mathrm{t}_{1 / 2}, \mathrm{MRT}$ ) of group II normal and diabetic rats, may be due to enhancing absorption or by inhibiting CYP3A responsible for metformin metabolism. Rate of absorption of metformin was not altered as there is no change in $\mathrm{T}_{\max }$ of both groups. So, the decreased volume of distribution may be due to metabolic inhibition of metformin by BA.

Erythromycin-N-demethylation assay further confirm the inhibitory influence of BA on CYP3A activity. These results are in accordance with the earlier in-vitro studies of BA metabolic inhibition on CYP3A4 enzyme in human liver microsomes [9]. 
Citation: Samala $S$ and Veeresham C. Boswellic acids Pretreatment Enhances the Bioavailability and Hypoglycemic action of Metformin in Rats: Involvement of CYP3A Inhibition. Int J Pharm Pharmacol 2018; 2: 132. doi: $\underline{10.31531 / 2581-3080.1000132}$

Table 1: Mean pharmacokinetic parameters of metformin in different groups of normal and STZ-induced diabetic rats.

\begin{tabular}{|l|l|l|l|l|}
\hline \multirow{2}{*}{ PK Parameter } & \multicolumn{2}{|c|}{ Metformin } & \multicolumn{2}{c|}{ Metformin + BA } \\
\cline { 2 - 5 } & Normal & Diabetic & Normal & Diabetic \\
\hline $\mathrm{C}_{\max }(\mu \mathrm{g} / \mathrm{ml})$ & $7.56 \pm 0.14$ & $11.58 \pm 0.13$ & $11.45 \pm 0.20^{* *}$ & $28.53 \pm 0.27^{* *}$ \\
\hline $\mathrm{T}_{\max }(\mathrm{h})$ & 2 & 2 & 2 & 2 \\
\hline $\mathrm{AUC}_{0-\mathrm{n}}(\mu \mathrm{g} / \mathrm{ml} \mathrm{h})$ & $34.06 \pm 0.18$ & $64.16 \pm 0.61$ & $70.49 \pm 1.29^{* *}$ & $236.15 \pm 0.36^{* *}$ \\
\hline $\mathrm{AUC}_{\mathrm{tot}}(\mu \mathrm{g} / \mathrm{ml} \mathrm{h})$ & $36.07 \pm 0.27$ & $71.52 \pm 0.74$ & $85.03 \pm 3.29^{* *}$ & $373.31 \pm 4.88^{* *}$ \\
\hline $\mathrm{t}_{1 / 2}(\mathrm{~h})$ & $2.6 \pm 0.11$ & $3.34 \pm 0.04$ & $4.29 \pm 0.29^{* *}$ & $7.76 \pm 0.20^{* *}$ \\
\hline $\mathrm{MRT}(\mathrm{h})$ & $4.93 \pm 0.11$ & $5.84 \pm 0.04$ & $7.20 \pm 0.35^{* *}$ & $11.97 \pm 0.25^{* *}$ \\
\hline $\mathrm{CL}(\mathrm{L} / \mathrm{h})$ & $8.66 \pm 2.5$ & $4.41 \pm 0.6$ & $3.72 \pm 0.22^{* *}$ & $2.12 \pm 0.1^{* *}$ \\
\hline $\mathrm{Vd}(\mathrm{L})$ & $32.09 \pm 8.1$ & $21.14 \pm 3.8$ & $23.40 \pm 1.48^{* *}$ & $10.46 \pm 2.6^{* *}$ \\
\hline $\mathrm{N}$ & & & &
\end{tabular}

Note: All values are expressed as mean $\pm \operatorname{SD}(n=6) .{ }^{*} \mathrm{p}<0.05 ;{ }^{* *} \mathrm{p}<0.01$ considered as significant when compared with metformin control. ${ }^{a}$ Definitions of the parameters: $\mathbf{C}_{\max }$ : Peak serum concentration; $\mathbf{T}_{\max }$ : Time to reach peak serum concentration; $\mathbf{A} \mathbf{U C}_{\mathbf{0 t o n}}$ : Area under serum concentration/time plot until the last quantifiable value; $\mathbf{A} \mathbf{U C}_{\text {total }}$ : Area under serum concentration/time plot extrapolated to infinity; $\mathbf{t}_{1 / 2}$ : Terminal half-life; MRT: Average mean residence time; CL: Total clearance; Vd: Volume of distribution.

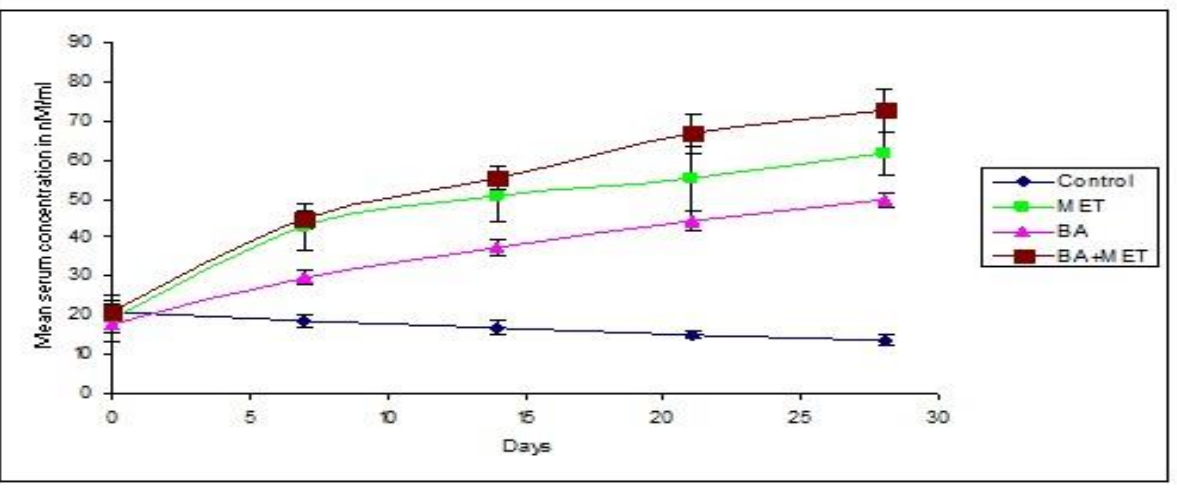

Figure 1: Effect of sub-acute pretreatment of BA and metformin on total antioxidant status of STZ-induced diabetic rats.

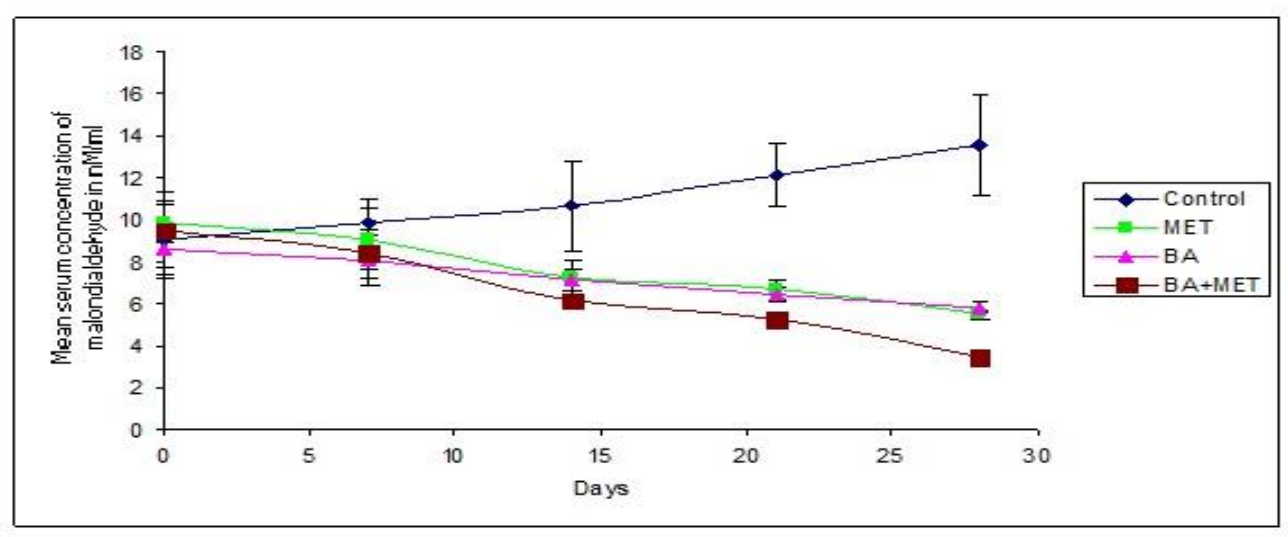

Figure 2: Effect of sub-acute pretreatment of BA and metformin on lipid peroxide levels of STZ-induced diabetic rats. 
Citation: Samala $S$ and Veeresham C. Boswellic acids Pretreatment Enhances the Bioavailability and Hypoglycemic action of Metformin in Rats: Involvement of CYP3A Inhibition. Int J Pharm Pharmacol 2018; 2: 132. doi: $\underline{10.31531 / 2581-3080.1000132}$

The results of antihyperglycemic study are depicted in Table 2 . At $6^{\text {th }} \mathrm{hr}$, maximum reduction of serum glucose level $44.35 \%$ was observed in group IV, when compared to group II (40.98\%) and group III $(26.65 \%)$. These results suggest that the enhancement of glucose reduction capacity of metformin in diabetic rats along with BA.
In glucose tolerance test all the groups shown significant $(\mathrm{p}<0.01)$ increase in glucose threshold within $30 \mathrm{~min}$ of glucose loading and the effects persisted till 120 min and results are depicted in Table 3.

Table 2: Comparison of mean serum glucose levels and percentage reduction of serum glucose level of Group II, Group III and Group IV with Group I in STZ-induced diabetic rats.

\begin{tabular}{|c|c|c|c|c|c|c|c|c|c|}
\hline \multirow{2}{*}{$\begin{array}{c}\text { Group } \\
\text { No }\end{array}$} & \multirow{2}{*}{ Treatment } & \multirow{2}{*}{$\begin{array}{c}\text { Dose } \\
(\mathrm{mg} / \mathrm{kg})\end{array}$} & \multicolumn{7}{|c|}{ Blood glucose level (mg/dl) at different hours } \\
\hline & & & $\mathbf{0 ~ h}$ & $2 \mathrm{~h}$ & $4 \mathrm{~h}$ & $6 \mathrm{~h}$ & $8 \mathrm{~h}$ & $12 \mathrm{~h}$ & $24 \mathrm{~h}$ \\
\hline I & Control & --- & $\begin{array}{l}270.5 \\
\pm 8.7\end{array}$ & $\begin{array}{c}269.9 \pm 9.2 \\
(0.22 \%)\end{array}$ & $\begin{array}{c}269.6 \pm 5.8 \\
(0.33 \%)\end{array}$ & $\begin{array}{c}268.9 \pm 7.2 \\
(0.59 \%)\end{array}$ & $\begin{array}{c}269.5 \pm 8.6 \\
(0.37 \%)\end{array}$ & $\begin{array}{c}269.4 \pm 6.9 \\
(0.41 \%)\end{array}$ & $\begin{array}{c}270.2 \pm 9.8 \\
(0.11 \%)\end{array}$ \\
\hline II & MET & 100 & $\begin{array}{l}282.1 \\
\pm 9.2\end{array}$ & $\begin{array}{l}247.8 \pm 7.8 \\
(12.16 \%)^{* *}\end{array}$ & $\begin{array}{l}205.2 \pm 5.4 \\
(27.26 \%)^{* *}\end{array}$ & $\begin{array}{l}166.5 \pm 8.1 \\
(40.98 \%)^{* *}\end{array}$ & $\begin{array}{l}192.8 \pm 6.5 \\
(31.66 \%)^{* *}\end{array}$ & $\begin{array}{l}239.8 \pm 9.5 \\
(14.99 \%)^{* *}\end{array}$ & $\begin{array}{c}276.3 \pm 8.4 \\
(2.06 \%)^{*}\end{array}$ \\
\hline III & BA & 100 & $\begin{array}{l}265.3 \\
\pm 9.8\end{array}$ & $\begin{array}{c}248.6 \pm 7.5 \\
(6.29 \%)^{* *}\end{array}$ & $\begin{array}{l}219.4 \pm 6.7 \\
(17.30 \%)^{* *}\end{array}$ & $\begin{array}{c}194.6 \pm \\
11.2 \\
(26.65 \%)^{* *}\end{array}$ & $\begin{array}{l}216.8 \pm 8.9 \\
(18.28 \%)^{* *}\end{array}$ & $\begin{array}{l}237.5 \pm 6.8 \\
(10.48 \%)^{* *}\end{array}$ & $\begin{array}{c}261.6 \pm 8.1 \\
(1.39 \%)^{*}\end{array}$ \\
\hline IV & $\begin{array}{l}\mathrm{BA}+ \\
\mathrm{MET}\end{array}$ & $100+100$ & $\begin{array}{c}295.6 \\
\pm \\
12.5 \\
\end{array}$ & $\begin{array}{l}253.5 \pm 8.4 \\
(14.24 \%)^{* *}\end{array}$ & $\begin{array}{l}204.8 \pm 7.2 \\
(30.72 \%)^{* *}\end{array}$ & $\begin{array}{l}164.5 \pm 7.9 \\
(44.35 \%)^{* *}\end{array}$ & $\begin{array}{l}195.2 \pm 9.1 \\
(33.96 \%)^{* *}\end{array}$ & $\begin{array}{l}242.4 \pm 9.6 \\
(17.99 \%)^{* *}\end{array}$ & $\begin{array}{l}265.4 \pm 6.6 \\
(10.22 \%)^{* * *}\end{array}$ \\
\hline
\end{tabular}

Note: Values are expressed as mean $\pm \mathrm{SD}(\mathrm{n}=6),{ }^{*} \mathrm{p}<0.05 ;{ }^{* *} \mathrm{p}<0.01$ considered as significant when compared with Group I at respective time interval.

Table 3: Comparison of oral glucose tolerance and percentage reduction of serum glucose level of Group II, Group III and Group IV with Group I in STZ-induced diabetic rats.

\begin{tabular}{|c|c|c|c|c|c|c|c|}
\hline \multirow{2}{*}{$\begin{array}{c}\text { Group } \\
\text { No }\end{array}$} & \multirow{2}{*}{ Treatment } & \multirow{2}{*}{$\begin{array}{c}\text { Dose } \\
(\mathrm{mg} / \mathrm{kg})\end{array}$} & \multicolumn{5}{|c|}{ Blood glucose levels (mg/dl) at different time intervals } \\
\hline & & & 0 min & $30 \mathrm{~min}$ & $60 \mathrm{~min}$ & $90 \mathrm{~min}$ & $120 \mathrm{~min}$ \\
\hline I & Control & - & $\begin{array}{c}305.2 \pm \\
5.8\end{array}$ & $\begin{array}{c}291.6 \pm 9.4 \\
(4.46 \%)\end{array}$ & $\begin{array}{c}281.8 \pm 7.6 \\
(7.67 \%)\end{array}$ & $\begin{array}{c}275.1 \pm 9.2 \\
(9.86 \%)\end{array}$ & $\begin{array}{c}266.4 \pm 6.3 \\
(12.71 \%)\end{array}$ \\
\hline II & MET & 100 & $\begin{array}{c}332.6 \pm \\
8.2\end{array}$ & $\begin{array}{c}304.2 \pm 7.5 \\
(8.54 \%)^{* *}\end{array}$ & $\begin{array}{l}272.5 \pm 8.8 \\
(18.07 \%)^{* *}\end{array}$ & $\begin{array}{l}235.4 \pm 6.5 \\
(29.22 \%)^{* *}\end{array}$ & $\begin{array}{l}206.8 \pm 5.8 \\
(37.82 \%)^{* *}\end{array}$ \\
\hline III & BA & 100 & $\begin{array}{c}325.3 \pm \\
9.1\end{array}$ & $\begin{array}{c}300.1 \pm 13.8 \\
(7.75 \%)^{* *}\end{array}$ & $\begin{array}{l}278.5 \pm 5.8 \\
(14.39 \%)^{* *}\end{array}$ & $\begin{array}{l}245.2 \pm 7.6 \\
(24.62 \%)^{* *}\end{array}$ & $\begin{array}{l}228.5 \pm 9.6 \\
(29.76 \%)^{* *}\end{array}$ \\
\hline IV & $\mathrm{BA}+\mathrm{MET}$ & $100+100$ & $\begin{array}{c}346.8 \pm \\
6.4\end{array}$ & $\begin{array}{l}305.5 \pm 8.6 \\
(11.91 \%)^{* *}\end{array}$ & $\begin{array}{l}268.4 \pm 9.8 \\
(22.61 \%)^{* *}\end{array}$ & $\begin{array}{c}230.8 \pm 10.4 \\
(33.45 \%)^{* *}\end{array}$ & $\begin{array}{l}201.6 \pm 8.3 \\
(41.87 \%)^{* *}\end{array}$ \\
\hline
\end{tabular}

Note: All values are expressed as mean $\pm \mathrm{SD}(\mathrm{n}=6),{ }^{*} \mathrm{p}<0.05 ;{ }^{* *} \mathrm{p}<0.01$ considered as significant when compared with Group I at respective time interval.

The body weight of diabetic control group rats was gradually decreased, whereas in all other groups it was increased significantly from 7 days onwards to 28 days, which indicates that these drugs do not have any effect on degradation of depot fat to maintain the body weight. The effect of the BA-metformin in reducing the blood glucose levels was gradually increased and was maximum after 28 days showing $47.83 \%$. The 
Citation: Samala $S$ and Veeresham C. Boswellic acids Pretreatment Enhances the Bioavailability and Hypoglycemic action of Metformin in Rats: Involvement of CYP3A Inhibition. Int J Pharm Pharmacol 2018; 2: 132. doi: $\underline{10.31531 / 2581-3080.1000132}$

significant antihyperglycemic effect of the BAmetformin was well comparable to that of the standard drug, metformin $(43.37 \%)$ and BA $(33.10 \%)$ alone pretreated group at all time intervals of the study shown in Table 4. From these results, combination of these drugs has shown more antihyperglycemic effect than alone treated drugs.

Table 4: Effect of BSE, BA and metformin on body weight and blood glucose levels in STZ - induced diabetic rats in sub-acute study (28 days).

\begin{tabular}{|c|c|c|c|c|c|c|c|c|c|c|c|}
\hline \multirow{3}{*}{ Groups } & \multirow{3}{*}{$\begin{array}{c}\text { Dose } \\
(\mathbf{m g} / \mathbf{k g})\end{array}$} & \multicolumn{5}{|c|}{ Body weight in grams } & \multicolumn{5}{|c|}{ Blood glucose levels (mg/dl) } \\
\hline & & \multicolumn{5}{|c|}{ After } & \multicolumn{5}{|c|}{ After } \\
\hline & & $\begin{array}{c}1^{\text {st }} \\
\text { day }\end{array}$ & $\begin{array}{c}7 \\
\text { days }\end{array}$ & $\begin{array}{c}14 \\
\text { days }\end{array}$ & $\begin{array}{c}21 \\
\text { days }\end{array}$ & $\begin{array}{c}28 \\
\text { days }\end{array}$ & $\begin{array}{c}1^{\text {st }} \\
\text { day }\end{array}$ & 7 days & 14 days & 21 days & 28 days \\
\hline $\begin{array}{l}\text { Diabetic } \\
\text { Control - I }\end{array}$ & - & $\begin{array}{l}210.5 \\
\pm 8.2 \\
\end{array}$ & $\begin{array}{l}195.2 \\
\pm 5.6 \\
\end{array}$ & $\begin{array}{l}180.5 \\
\pm 7.2\end{array}$ & $\begin{array}{l}170.8 \\
\pm 4.1\end{array}$ & $\begin{array}{r}150.4 \\
\pm 8.8 \\
\end{array}$ & $\begin{array}{r}330.1 \\
\pm 9.2 \\
\end{array}$ & $\begin{array}{c}331.8 \pm \\
12.5 \\
(0.51 \%) \\
\end{array}$ & $\begin{array}{c}329.4 \pm 7.8 \\
(0.21 \%)\end{array}$ & $\begin{array}{c}331.6 \pm 5.4 \\
(0.45 \%)\end{array}$ & $\begin{array}{c}333.5 \pm \\
9.6 \\
(1.03 \%) \\
\end{array}$ \\
\hline MET - II & 100 & $\begin{array}{l}215.8 \\
\pm 6.2 \\
\end{array}$ & $\begin{array}{c}220.6 \\
\pm 5.1 \\
\end{array}$ & $\begin{array}{c}230.4 \\
\pm 5.8 \\
\end{array}$ & $\begin{array}{l}235.2 \\
\pm 6.8\end{array}$ & $\begin{array}{r}240.9 \\
\pm 4.5 \\
\end{array}$ & $\begin{array}{l}315.2 \\
\pm 6.4\end{array}$ & $\begin{array}{c}285.8 \pm 9.8 \\
(9.33 \%)^{* * *}\end{array}$ & $\begin{array}{l}247.6 \pm 7.5 \\
(21.45 \%)^{* *}\end{array}$ & $\begin{array}{l}200.4 \pm 6.8 \\
(36.42 \%)^{* *}\end{array}$ & $\begin{array}{c}178.5 \pm \\
4.6 \\
(43.37 \%)^{* * *}\end{array}$ \\
\hline BA - III & 100 & $\begin{array}{l}160.4 \\
\pm 9.3\end{array}$ & $\begin{array}{l}165.8 \\
\pm 6.4 \\
\end{array}$ & $\begin{array}{l}172.6 \\
\pm 4.5\end{array}$ & $\begin{array}{l}180.5 \\
\pm 7.8 \\
\end{array}$ & $\begin{array}{l}190.2 \\
\pm 8.1 \\
\end{array}$ & $\begin{array}{c}320.8 \\
\pm 9.8 \\
\end{array}$ & $\begin{array}{c}298.5 \pm \\
12.2 \\
(6.95 \%)^{* *}\end{array}$ & $\begin{array}{l}274.1 \pm 7.5 \\
(14.56 \%)^{* *}\end{array}$ & $\begin{array}{l}238.3 \pm 4.9 \\
(25.72 \%)^{* *}\end{array}$ & $\begin{array}{c}214.6 \pm \\
6.5 \\
(33.10 \%)^{* *}\end{array}$ \\
\hline BA+MET-IV & $100+100$ & $\begin{array}{l}150.6 \\
\pm 6.8\end{array}$ & $\begin{array}{l}160.7 \\
\pm 9.2\end{array}$ & $\begin{array}{l}175.8 \\
\pm 8.4\end{array}$ & $\begin{array}{l}190.4 \\
\pm 7.1\end{array}$ & $\begin{array}{l}210.5 \\
\pm 9.8\end{array}$ & $\begin{array}{r}345.4 \\
\pm 11.2\end{array}$ & $\begin{array}{l}300.6 \pm 9.5 \\
(12.97 \%)^{* *}\end{array}$ & $\begin{array}{l}256.8 \pm 8.5 \\
(25.65 \%)^{* *}\end{array}$ & $\begin{array}{l}205.4 \pm 6.6 \\
(40.53 \%)^{* *}\end{array}$ & $\begin{array}{c}180.2 \pm \\
8.8 \\
(47.83 \%)^{* *}\end{array}$ \\
\hline
\end{tabular}

Note: All values are expressed as mean $\pm \mathrm{SD}, \mathrm{n}=6$; Values given in the parenthesis are the percent increase or decrease in respective parameter level; ${ }^{*} \mathrm{p}<0.05 ;{ }^{* *} \mathrm{p}<0.01$ when compared with control at the respective time interval.

Comparison of different serum biochemical parameters in sub-acute study are shown in Table 5. There is a significant effect $(\mathrm{p}<0.01)$ of the BA-metformin in reducing serum GOT and GPT levels was maximum after 28 days showing $33.58 \%$ and $37.96 \%$ respectively and was well comparable to that of the standard drug, metformin $(26.41 \%, 31.25 \%)$ and BA alone pretreated group $(24.83 \%, 23.37 \%)$. Gluconeogenesis and ketogenesis occur in diabetes due to high levels of SGOT and SGPT, but these results shown more antidiabetogenic effect in combination of these drugs [21].

Table 5: Comparison of different groups of $\mathrm{AD}$ and metformin on serum biochemical parameters in STZ-induced diabetic rats (Sub acute study).

\begin{tabular}{|c|c|c|c|c|c|c|c|c|c|c|c|c|}
\hline \multirow[b]{2}{*}{ Groups } & \multicolumn{2}{|c|}{$\begin{array}{c}\text { Serum Insulin levels in } \\
\mu \mathrm{IU} / \mathrm{ml}\end{array}$} & \multicolumn{2}{|c|}{ SGOT (U/L) } & \multicolumn{2}{|c|}{ SGPT (U/L) } & \multicolumn{2}{|c|}{$\begin{array}{c}\text { Serum Triglyceride } \\
\text { levels (mg/dl) }\end{array}$} & \multicolumn{2}{|c|}{$\begin{array}{c}\text { Serum } \\
\text { Cholesterol } \\
(\mathbf{m g} / \mathbf{d l})\end{array}$} & \multicolumn{2}{|c|}{$\begin{array}{c}\text { Serum Total } \\
\text { protein }(\mathrm{mg} / \mathrm{dl})\end{array}$} \\
\hline & $1^{\text {st }}$ day & $\begin{array}{c}\text { After } 28 \\
\text { days }\end{array}$ & $\begin{array}{c}1^{\text {st }} \\
\text { day }\end{array}$ & $\begin{array}{c}\text { After } 28 \\
\text { days }\end{array}$ & $\begin{array}{c}1^{\text {st }} \\
\text { day }\end{array}$ & $\begin{array}{c}\text { After } 28 \\
\text { days }\end{array}$ & $1^{\text {st }}$ day & $\begin{array}{c}\text { After } 28 \\
\text { days }\end{array}$ & $\begin{array}{l}1 \text { st } \\
\text { day }\end{array}$ & $\begin{array}{c}\text { After } 28 \\
\text { days }\end{array}$ & $\begin{array}{l}1 \text { st } \\
\text { day }\end{array}$ & $\begin{array}{c}\text { After } 28 \\
\text { days }\end{array}$ \\
\hline $\begin{array}{c}\text { Diabetic } \\
\text { Control } \\
\text { - I }\end{array}$ & $8.2 \pm 0.3$ & $\begin{array}{l}7.99 \pm 0.2 \\
(-2.56 \%)\end{array}$ & $\begin{array}{l}145.2 \\
\pm 5.4\end{array}$ & $\begin{array}{c}154.4 \pm 8.6 \\
(-6.34 \%)\end{array}$ & $\begin{array}{l}160.3 \\
\pm 6.8\end{array}$ & $\begin{array}{c}166.1 \pm 9.5 \\
(-3.62 \%)\end{array}$ & $\begin{array}{l}150.6 \\
\pm 7.8\end{array}$ & $\begin{array}{c}145.5 \pm \\
9.4(- \\
3.39 \%)\end{array}$ & $\begin{array}{c}140 . \\
8 \pm \\
8.1\end{array}$ & $\begin{array}{c}134.6 \pm \\
6.4(- \\
4.4 \%)\end{array}$ & $\begin{array}{c}4.1 \\
\pm \\
0.1\end{array}$ & $\begin{array}{l}4.0 \pm 0.2 \\
(-2.44 \%)\end{array}$ \\
\hline $\begin{array}{l}\text { MET - } \\
\text { II }\end{array}$ & +0.8 & $\begin{array}{c}13.2 \pm 1.5 \\
(38.95 \%)^{*} \\
*\end{array}$ & $\begin{array}{r}120.4 \\
\pm 5.8 \\
\end{array}$ & $\begin{array}{l}88.6 \pm 7.8 \\
(26.41 \%)^{* *}\end{array}$ & $\begin{array}{l}140.8 \\
\pm 7.4 \\
\end{array}$ & $\begin{array}{l}96.8 \pm 5.9 \\
(31.25 \%)^{* *}\end{array}$ & $\begin{array}{l}155.8 \\
\pm 5.4 \\
\end{array}$ & $\begin{array}{c}104.2 \pm \\
8.6 \\
(33.12 \%)^{* *} \\
\end{array}$ & $\begin{array}{c}150 \\
4 \pm \\
5.8 \\
\end{array}$ & $\begin{array}{l}98.6 \pm 9.6 \\
(34.44 \%)^{* *}\end{array}$ & $\begin{array}{c}4.4 \\
\pm \\
0.5 \\
\end{array}$ & $\begin{array}{c}6.0 \pm 0.8 \\
(36.36 \%)^{* *}\end{array}$ \\
\hline BA - III & $8.5 \pm 0.2$ & $\begin{array}{c}10.9 \pm 0.5 \\
(28.24 \%)^{*} \\
*\end{array}$ & $\begin{array}{l}130.5 \\
\pm 5.9 \\
\end{array}$ & $\begin{array}{l}98.1 \pm 4.7 \\
(24.83 \%)^{* *}\end{array}$ & $\begin{array}{l}142.5 \\
\pm 9.5 \\
\end{array}$ & $\begin{array}{l}109.2 \pm 6.8 \\
(23.37 \%)^{* *}\end{array}$ & $\begin{array}{l}160.1 \\
\pm 6.2 \\
\end{array}$ & $\begin{array}{c}114.5 \pm \\
8.2 \\
(28.48 \%)^{* * *}\end{array}$ & $\begin{array}{c}152 . \\
8 \pm \\
7.5\end{array}$ & $\begin{array}{c}104.8 \pm \\
7.9 \\
(31.41 \%)^{* *}\end{array}$ & $\begin{array}{c}3.6 \\
\pm \\
0.1 \\
\end{array}$ & $\begin{array}{c}4.6 \pm 0.3 \\
(27.78 \%)^{* *}\end{array}$ \\
\hline $\begin{array}{c}\mathrm{BA}+\mathrm{ME} \\
\mathrm{T}-\mathrm{IV} \\
\end{array}$ & $8.2 \pm 1.4$ & $\begin{array}{c}11.8 \pm 0.9 \\
(43.90 \%)^{*} \\
*\end{array}$ & $\begin{array}{l}135.8 \\
\pm 9.1 \\
\end{array}$ & $\begin{array}{l}90.2 \pm 7.3 \\
(33.58 \%)^{* *}\end{array}$ & $\begin{array}{l}145.4 \\
\pm 8.6 \\
\end{array}$ & $\begin{array}{l}90.2 \pm 9.4 \\
(37.96 \%)^{* *}\end{array}$ & $\begin{array}{l}150.8 \\
\pm 6.8 \\
\end{array}$ & $\begin{array}{l}92.5 \pm 7.9 \\
(38.66 \%)^{* *}\end{array}$ & $\begin{array}{l}158 . \\
2 \pm \\
6.5\end{array}$ & $\begin{array}{l}96.1 \pm 9.2 \\
(39.25 \%)^{* *}\end{array}$ & $\begin{array}{c}3.5 \\
\pm \\
0.7 \\
\end{array}$ & $\begin{array}{l}4.95 \pm 0.6 \\
(41.43 \%)^{* * *}\end{array}$ \\
\hline
\end{tabular}

Note: All values are expressed as mean $\pm \mathrm{SD}, \mathrm{n}=6$; Values given in the parenthesis are the percent increase or decrease in respective parameter level; ${ }^{*} \mathrm{p}<0.05$; ${ }^{* *} \mathrm{p}<0.01$ when compared with control at the respective time interval. 
Citation: Samala $S$ and Veeresham C. Boswellic acids Pretreatment Enhances the Bioavailability and Hypoglycemic action of Metformin in Rats: Involvement of CYP3A Inhibition. Int J Pharm Pharmacol 2018; 2: 132. doi: $10.31531 / 2581-3080.1000132$

The percent reduction in serum triglyceride and cholesterol levels of BA-metformin treated group was $38.66 \%$ and $39.25 \%$, while it was $33.12 \%, 34.44 \%$ in standard group and $28.48 \%, 31.41 \%$ in BA alone pretreated group. This phenomenon clearly indicates that these drugs in combination have more antihypertriglyceridemic and antihypercholesterolemic activity than alone pretreated groups and with control group. The significant increasing effect $(\mathrm{p}<0.01)$ of the BA-metformin group on serum total proteins level was maximum after 28 days showing $41.43 \%$ and was well comparable to that of the standard $(36.36 \%)$ and BA (27.78\%) alone pretreated groups.

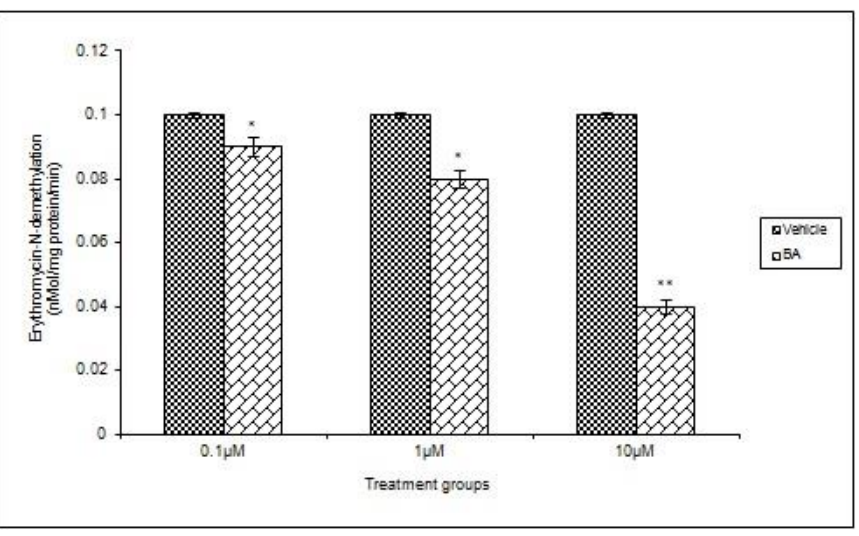

Figure 3: Influence of BA on CYP3A activity in intestinal microsomes, [Data are presented as mean \pm SD $(n=6) .{ }^{*} \mathrm{p}<0.05,{ }^{* *} \mathrm{p}<0.01$ compared with vehicle control].

Further, the increased serum total protein level brought out by these drugs explains its antidiabetogenic effect as the reduction in protein level takes place in diabetes due to deficiency of insulin, which stimulates uptake of aminoacids into muscle and increases protein synthesis [22]. The significant increasing effect $(p<0.01)$ of the BA-metformin group on serum insulin levels was maximum after 28 days showing $43.90 \%$ and was well comparable to that of the standard metformin $(38.95 \%)$ and BA (28.24\%) alone pretreated groups. This significant increase in serum insulin levels indicates that BA might have exhibited the antihyperglycemic effect like metformin, i.e. by insulin secretogogue activity [23].

The effect of these drugs on oxidative stress markers were shown in Figures 3 and 4. In group IV found gradually increased $(\mathrm{p}<0.01)$ in total antioxidant status, whereas the lipid peroxide levels were found decreased significantly $(\mathrm{p}<0.01)$, when compared with all other groups. This indicates the significant increase in free radical scavenging capacity of these drugs when compared to control group. So, BA offer significant protection against the oxidative stress induced by diabetes and interfere with PK and PD.

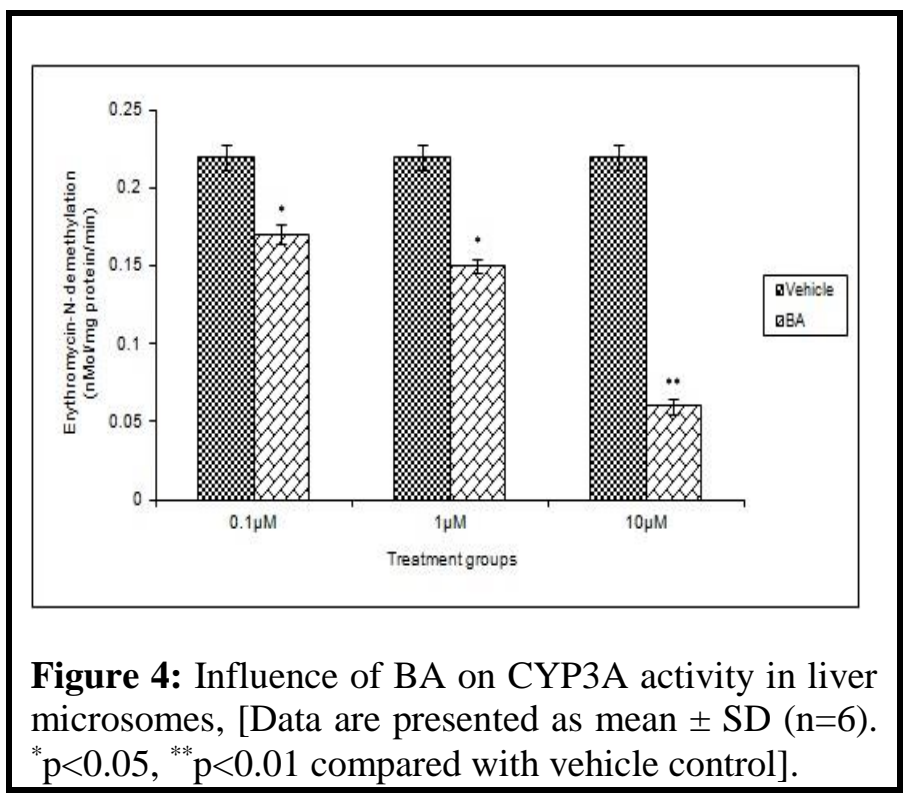

The present study indicated that BA affects the metabolism of metformin, possibly by the inhibition of CYP3A and increases the bioavailability of concomitantly administered metformin. Combination of metformin with BA considerably enhances the glucoselowering effect of metformin. Hence, metformin doses may require special attention if used along with BA or Boswellia serrata extract containing herbal preparations to avoid the complications.

\section{Acknowledgement}

The authors are thankful to Dr. Reddy's laboratories, Hyderabad, India for the gift samples of metformin and gliclazide. One of the author Sujatha Samala, wish to thank University Grants Commission, New Delhi for providing the financial assistance to carry out this work.

\section{References}

1. Dey L, Attele AS, Yuan CS. Alternative therapies for type 2 diabetes. Alternat Med Rev 2002; 7: 4558.

2. Chavez ML, Jordan MA, Chavez PI. Evidence based drug-herbal interactions. Life Sci 2006; 78: 2146-2157.

3. Shikha C, Tamanna N, Love Kumar S. Effect of Allium sativum on the pharmacokinetic of 
Citation: Samala $S$ and Veeresham C. Boswellic acids Pretreatment Enhances the Bioavailability and Hypoglycemic action of Metformin in Rats: Involvement of CYP3A Inhibition. Int J Pharm Pharmacol 2018; 2: 132. doi: $\underline{10.31531 / 2581-3080.1000132}$

metformin in rat plasma: A herb-drug interaction study. Der Pharma Chemica 2011; 3: 287-291.

4. Shravan Kumar D, Ramakrishna R, Kannappan. Effect of Gymnema sylvestre on the pharmacokinetics and pharmacodynamics of metformin in diabetic rats. J Pharma Res 2013; 1: 657-664.

5. Paranjpe P. Sallaki-Boswellia serrata. In: Indian Medicinal Plants-Forgotten Healers: A Guide to Ayurvedic Herbal Medicine. Chaukhamba Sanskrit Pratishthan Publishers, Delhi 2001; 233-234.

6. Gayathri B, Manjula N, Vinaykumar KS, et al. Pure compound from Boswellia serrata extract exhibits anti-inflammatory property in human PBMCs and mouse macrophages through inhibition of TNF $\alpha$, IL-1 $\beta, \quad N O$ and MAP kinases. Int $J$ Immunopharmacol 2007; 7: 473-482.

7. Sharma ML, Bani S, Singh GB. Anti-arthritic activity of boswellic acids in bovine serum albumin (BSA)-induced arthritis. Int J Immunopharmacol 1989; 11: 647-652.

8. Shehata AM, Quintanilla-Fend L, Bettio S, et al. Prevention of multiple low-dose streptozotocin (MLD-STZ) diabetes in mice by an extract from gum resin of Boswellia serrata (BE). Phytomed 2011; 18: 1037-1044.

9. Frank A, Unger M. Analysis of frankincense from various Boswellia species with inhibitory activity on human drug metabolizing cytochrome P450 enzymes using liquid chromatography mass spectrometry after automated on-line extraction. J Chromatogr A 2006; 112: 255-262.

10. Sujatha S, Veeresham C. Enhanced bioavailability of glimepiride in the presence of boswellic acids in streptozotocin-induced diabetic rat model. Nat Prod Chem Res 2013; 1: 1-6.

11. Riley V. Adaptation of orbital bleeding technique to rapid serial blood studies. Exp Biol Med 1960; 104: 751-754.

12. Tuitoek PJ, Ziari S, Tsin ATC, et al. Streptozotocininduced diabetes in rats is associated with impaired metabolic availability of vitamin A (retinol). Bri J Nutr 1996; 75: 615-622.
13. Wanjari MM, There AW, Tajne MR, et al. Rapid and simple RP-HPLC method for the estimation of metformin in rat plasma. Indian J Pharm Sci 2008; 70: 198-202.

14. Sudhir NU, Pankaj VD, Vijendra K, et al. Quercetin pretreatment increases the bioavailability of pioglitazone in rats: Involvement of CYP3A inhibition. Biochem Pharmacol 2008; 75: 16701676.

15. Nash T. The colorimetric estimation of formaldehyde by means of the Hantzsch reaction. Biochem J 1953; 55: 416-421.

16. Trinder P. Determination of blood glucose using 4amino phenazone as oxygen acceptor. J Clin Pathol 1969; 22: 246.

17. Sachin LB, Subhash LB. Interaction of aqueous extract of Pleurotus pulmonarius (Fr.) Quel. Champ with acarbose in alloxan induced diabetic mice. $\mathbf{J}$ Appl Biomed 2007; 5: 157-166.

18. Syed mansoor A, Vrushabendra swamy BM, Dhanapal PGR, et al. Antidiabetic activity of Terminalia catappa Linn. leaf extracts in alloxaninduced diabetic rats. Iranian $\mathbf{J}$ Pharmacol Ther 2005; 4: 36-39.

19. Reddy YN, Murthy SV, Krishna DR, et al. Role of free radicals and antioxidants in tuberculosis patients. Indian J Tuberculosis 2004; 51: 213-218.

20. Ohkawa H, Ohishi N, Yagi K. Assay for lipid peroxides in animal tissues by Thiobarbituric acid reaction. Analyt Biochem 1979; 95: 351-358.

21. Felig P, Marliss E, Ohman J, et al. Plasma amino acid levels in diabetic ketoacidosis. Diabetes 1970;19: 727-730.

22. Chakrabarti R, Rajagopalan R. Diabetes and insulin resistance associated disorders: Disease and the therapy. Cur Sci 2002; 83: 1533-1538.

23. Abdel-Zaher AO, Salim SY, Assaf MH, et al. Antidiabetic activity and toxicity of Zizyphus spinachristi leaves. J Ethnopharmacol 2005; 101: 129-138.

This manuscript was peer-reviewed

Mode of Review: Single-blinded

Academic Editor: Dr. Syed Sarim Imam

Copyright: (2018 Samala S, et al. This article is distributed under the terms of the Creative Commons Attribution 4.0 International License (http://creativecommons.org/licenses/by/4.0/), which permits unrestricted use, distribution, and reproduction in any medium, provided you give appropriate credit to the original author(s) and the source, provide a link to the Creative Commons license, and indicate if changes were made. 